\title{
Environmental aspects of the impact of the technical condition of motor vehicles on environmental pollution
}

The article presents selected aspects related to the influence of toxic components of exhaust gases from vehicle transport vehicles on environmental pollution and human health. The paper describes the quantitative structure of motor vehicles that are operating in Poland. The structure of used passenger cars that were imported from abroad and first registered in Poland was presented. The procedure for periodic control tests in exhaust emission diagnostic stations is also described. The results of the study allowed to distinguish a group of vehicles that did not meet the limits of pollution established by the legislator.

Key words: exhaust, operation, research, cars, environment

\section{Aspects of environmental pollution by motor vehicles}

The environmental pollution caused by motor vehicles is closely linked to the development of technology, and the technological revolution that has been observed for several decades in the world has led to an increase in the demand for energy. This triggers dangers, first of all the effects of burning all kinds of fuels. In the course of combustion, chemical compounds that are inactive for the environment, human life and animals are formed. Emissions to the atmosphere of large amounts of gases, mainly $\mathrm{CO}_{2}$, produce a greenhouse effect resulting in a steady increase in the average temperature of the ecosphere and associated undesirable meteorological phenomena [1]. The industrial activity of society is a source of influence for the change of the natural environment, the fabrication and development of the manufacturing process results in the emergence of a new category of environmental influences, not only quantitatively but qualitatively. The development of new manufacturing processes, as a result of technical progress, has become the source of previously unknown environmental effects [2]. Transport in Europe is responsible for harmful levels of air pollutants and a quarter of greenhouse gas emissions in the European Union. According to a recent report by the European Environment Agency, many of the resulting environmental problems can be resolved by stepping up efforts to meet the new objectives of the European Union. Although air pollution has decreased in the last two decades, it is still a serious problem in many areas. "European standards" for vehicles did not reduce $\mathrm{NO}_{2}$ emissions to levels set by law, although they generally contributed to significant improvements in air quality [3]. People living around high intensity roads are particularly exposed to excessive levels of pollution in the air. In 2010. The $\mathrm{NO}_{2}$ level, in excess of the legal restrictions, was registered in $44 \%$ of roadside monitoring stations. The concentration of PM10 dust in these places exceeded the limits of $33 \%$. These impurities have a direct effect on cardiovascular, lung, liver, spleen and blood [4].

Motor vehicles powered by internal combustion engines have the effect of polluting the atmosphere by emitting harmful substances such as carbon monoxide, hydrocarbons, nitrogen oxides, solids, and substances in low concen- trations, such as aldehydes, Sulfur compounds, phosphorus and others. Substances that pollute the atmosphere are: engine exhaust gases, engine crankcase and fuel supply system [5].

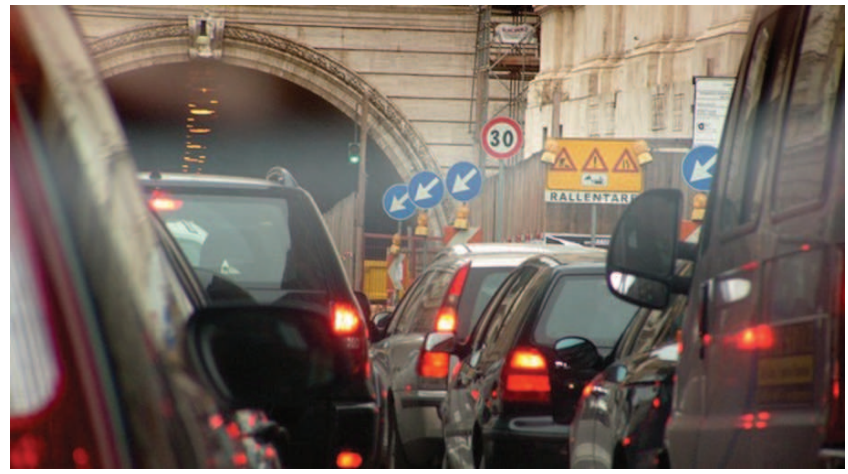

Fig. 1. Air pollution in urban agglomerations [4]

\section{Structure of motor vehicles in Poland}

In Poland, in the recent period of time, along with the economic growth, the number of motor vehicles in continuous use increased. In December 2015, 27409106 units were registered in Poland. [7] All vehicles, trucks, buses, motorcycles and more (Fig. 2). The largest group of passenger cars is 20723423 [7], which accounts for $75.6 \%$ of the overall condition of vehicles in Poland (Fig. 3). There is a problem of ensuring proper technical condition of vehicles that are in service for many years. The average age of passenger cars in operation in December 2015. In Poland it was 15.5 years [6].

Their technical condition is checked once a year in diagnostic tests during compulsory control tests. Over the past period, the number of vehicles registered per 1000 inhabitants has risen to 653 in Poland. The highest growth was achieved in passenger cars, reaching 502 copies [6].

Most of the vehicles that are currently in service were not registered for the first time as new in the country, were used abroad and then imported to Poland. In 2003year 35736 units were imported, and in subsequent years, the number of imported cars increased significantly to an average of 700000 units per year, the most imported. In December 2008years 
1103970 pcs. Until December 2015 the number of imported motor vehicles was 94522717 pieces [6].

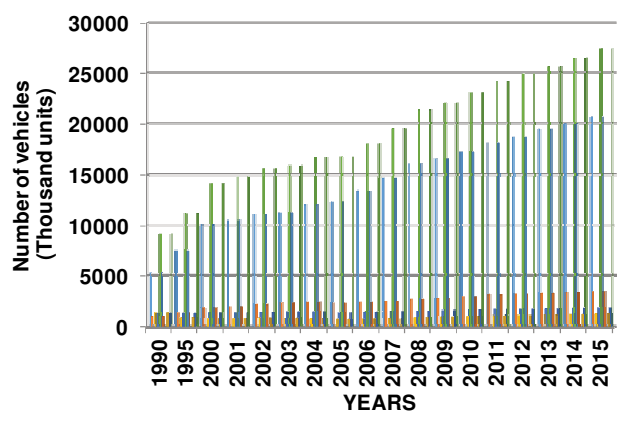

- Passengercars

Trucks

- Buses

Motorcycles

- Another

- Total

Passengercars

- Trucks

Buses

Motorcycles

- Another

- Total

Fig. 2. Motor vehicles registered [7]

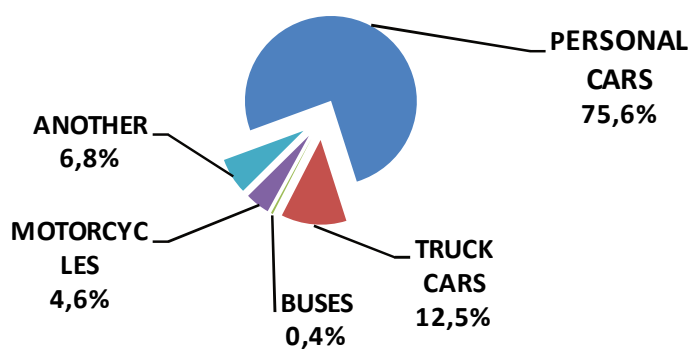

Fig. 3. Registered vehicles 2015 [8]

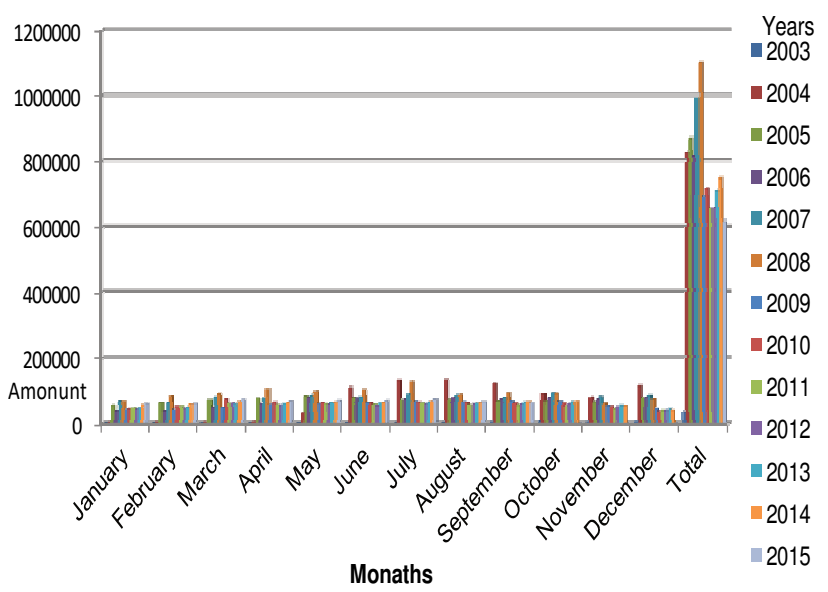

Fig. 4. Structure of used imported passenger cars [6]

\section{Vehicle inspection in diagnostic stations}

Existing legal regulations aim at guaranteeing road traffic safety participants only by vehicles that comply with accepted technical and safety standards.

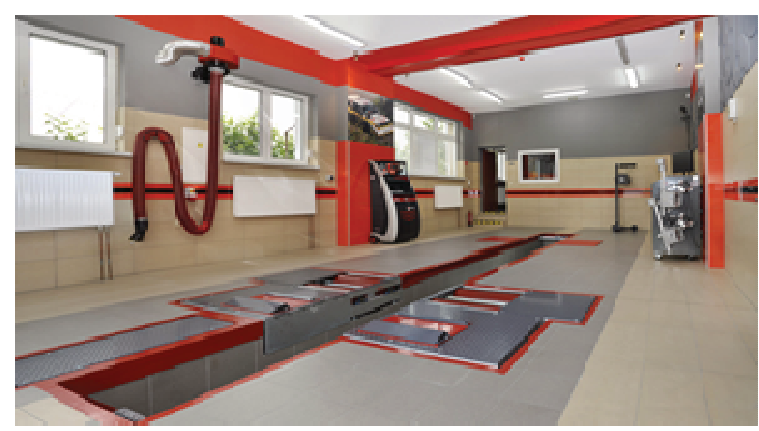

Fig. 5. Diagnostic station [9]
Table 1. Levels of gaseous pollutants and air excess coefficient $\lambda$ [12]

\begin{tabular}{|c|c|c|c|c|c|c|c|c|c|}
\hline \multirow[t]{4}{*}{ Lp } & \multirow[t]{4}{*}{ Vehicle } & \multirow{4}{*}{$\begin{array}{l}\text { Engine } \\
\text { speed }\end{array}$} & \multicolumn{7}{|c|}{ CO content in\% volume of exhaust gas } \\
\hline & & & \multicolumn{7}{|c|}{$\mathrm{HC}$ in ppm (particles per million) and $\lambda$ for a vehicle } \\
\hline & & & \multirow[t]{2}{*}{$\begin{array}{l}\text { Until } \\
\text { Sept. } \\
1986\end{array}$} & $\begin{array}{l}\text { From } 1 \\
\text { October } \\
1986 \text { to } \\
30 \text { June }\end{array}$ & \multicolumn{3}{|c|}{$\begin{array}{c}\text { From } 1 \text { July } 1995 \text { to } 30 \\
\text { April }\end{array}$} & \multicolumn{2}{|c|}{$\begin{array}{c}\text { Since May } 1 \\
2004\end{array}$} \\
\hline & & & & 1995 & & 2004 & & & \\
\hline \multirow[t]{2}{*}{1} & 2 & 3 & 4 & 5 & 6 & 7 & 8 & 9 & 10 \\
\hline & & & $\mathrm{CO}$ & $\mathrm{CO}$ & $\mathrm{CO}$ & $\mathrm{CH}$ & $\lambda$ & $\mathrm{CO}$ & $\lambda$ \\
\hline 1 & Motorcycle & Idle & 5,5 & 4,5 & 4,5 & - & - & 4,5 & - \\
\hline \multirow[t]{3}{*}{2} & \multirow{3}{*}{$\begin{array}{l}\text { Another } \\
\text { motor } \\
\text { vehicle }\end{array}$} & Idle & 4,5 & 3,5 & 0,5 & 100 & - & 0,3 & - \\
\hline & & $\begin{array}{l}2000 \\
\min ^{-1} \text { to }\end{array}$ & \multirow[t]{2}{*}{ - } & \multirow[t]{2}{*}{ - } & \multirow[t]{2}{*}{0,3} & \multirow[t]{2}{*}{100} & $0,97-$ & \multirow[t]{2}{*}{0,2} & \multirow[t]{2}{*}{$\begin{array}{r}0,97 \\
1,03\end{array}$} \\
\hline & & $\begin{array}{l}3000 \\
\min ^{-1}\end{array}$ & & & & & 1,03 & & \\
\hline
\end{tabular}

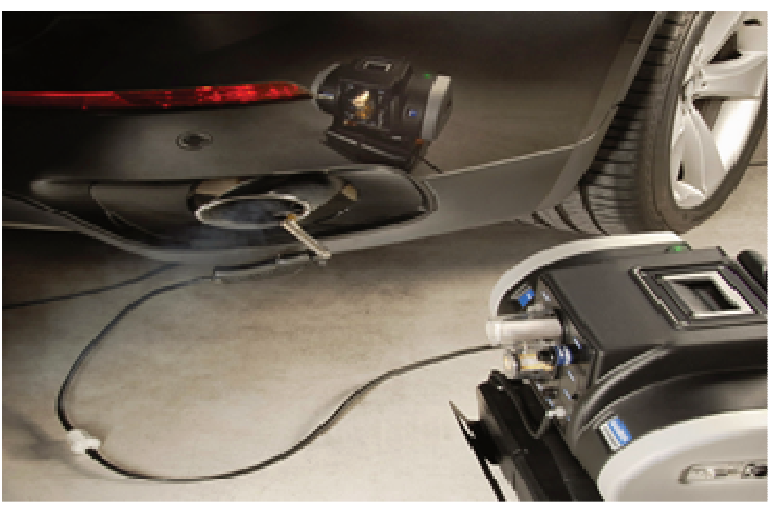

Fig. 6. Emission control [10]

Technical tests of vehicles are performed at the Vehicle Inspection Stations and consist of verifying that the vehicle meets the technical specifications of the regulations [12]. Measurement of gaseous emissions is carried out using a device designed to measure the concentrations of carbon monoxide $(\mathrm{CO})$, carbon dioxide $\left(\mathrm{CO}_{2}\right)$, hydrocarbons $(\mathrm{CH})$, oxygen $\left(\mathrm{O}_{2}\right)$, and lambda $(\lambda)$.

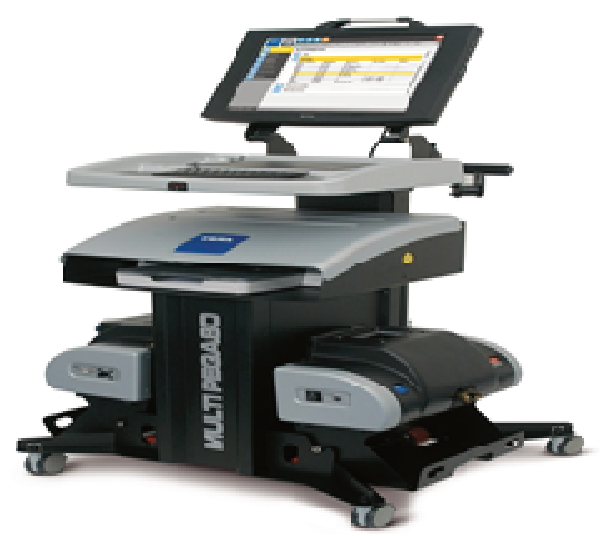

Fig. 7. Gasbox Autopower emission control device [10]

Table 2. Gasbox Autopower technical specification [10]

\begin{tabular}{|l|l|}
\hline Parameter & Value \\
\hline Dimensions & $460 \times 200 \times 250 \mathrm{~mm}$ \\
\hline Weight & $9 \mathrm{~kg}$ \\
\hline Power supply & $115-230 \mathrm{~V}$ \\
\hline Power consumption & $80 \mathrm{~W}$ \\
\hline Control system & ETS lub ID $<4 \mathrm{E}$ \\
\hline Technology & NDIR \\
\hline Response time & $<15 \mathrm{~s}$ \\
\hline Warm-up time & do $60 \mathrm{~s}$ \\
\hline
\end{tabular}




\subsection{Measurement execution}

Tests were carried out at the Vehicle Inspection Station on a randomly selected group of vehicles equipped with SI petrol engines fueled with petrol to determine the concentrations of the toxic exhaust gases of the used vehicles. The analysis was made according to the year of manufacture and mileage, which is the emission limit for engines mounted on vehicles. Concentration measurements were made at the gas emission test site, which is part of the compulsory equipment of the Vehicle Inspection Station [12]. Exhaust gas emission measurement was performed when the engine was heated above $70^{\circ} \mathrm{C}$ for engine oil and above $80^{\circ} \mathrm{C}$ for the coolant. The exhaust gas analyzer was introduced into the engine's exhaust system immediately before the measurement at a depth of at least $30 \mathrm{~cm}$. The engine's crankshaft rotational speed was maintained for more than 15 seconds and then lowered to idle speed [12].

\subsection{Findings}

The test results presented [11] were made on a 120 vehicle group during mandatory inspection at a selected vehicle inspection station (SKP). Figure 9 shows the results of the measurement of the carbon monoxide $(\mathrm{CO})$ content of exhaust gases from the engine, Made on low engine crankshaft rotation around $1000 \mathrm{rpm}$. The research shows that vehicles that were manufactured before 1995 do not meet the required pollution limits of about $36 \%$, produced after 1995 does not meet about 30\%, and vehicles that were produced after 2004 do not meet the requirements in about $10 \%$.

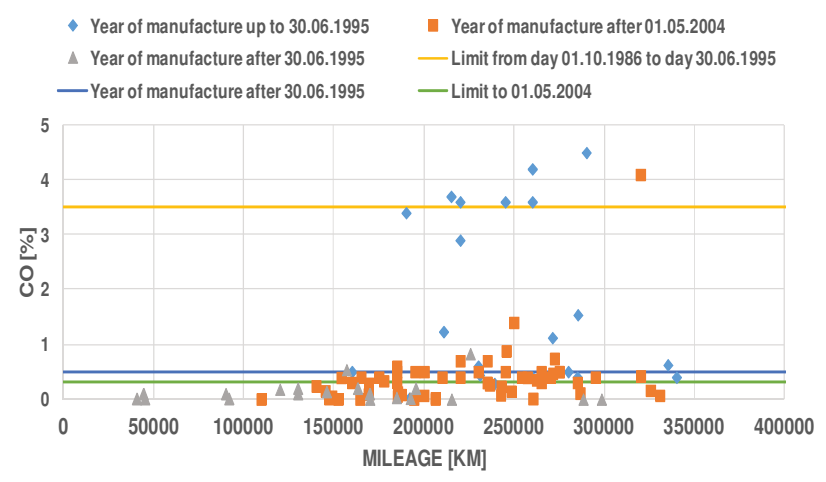

Fig. 8. CO test at idle [11]

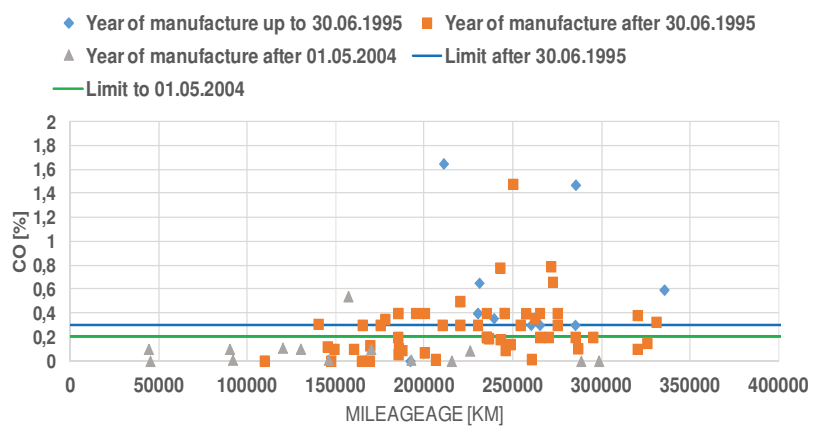

Fig. 9. CO study at elevated speed [11]

Figure 10 shows the test results $(\mathrm{CO})$, which were made at elevated engine revolutions (2000-3000 rpm). Research shows that groups of vehicles that were produced after 1995 do not meet the required level of gaseous pollutants in about 28\% while vehicles produced after 2004 in about 5\%.

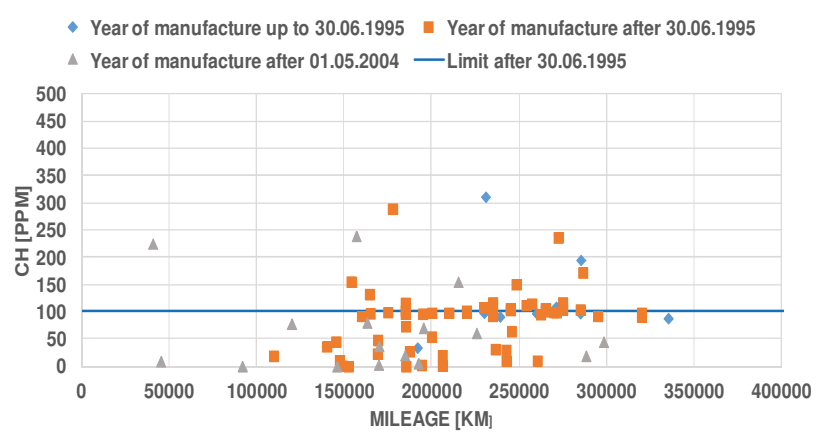

Fig. 10. Examination $\mathrm{HC}$ at idle [11]

The results of hydrocarbon (HC) research shown in Fig. 11 were made only for the group of vehicles that were produced between 1995 and 2004, as only this group of vehicles is subject to mandatory testing (HC). The research was done at a low crankshaft engine speed of around $1000 \mathrm{rpm}$, from the group of vehicles about $30 \%$ did not meet the requirements.

Hydrocarbon test at elevated engine crankshaft speed 2000-3000 rpm (Fig. 12). The research showed that a group of vehicles that do not meet the requirements is about $15 \%$.

- Year of manufacture up to 30.06 .1995 Year of manufacture after 30.06 .1995

$\Delta$ Year of manufacture after 01.05.2004 — Limit after 30.06.1995

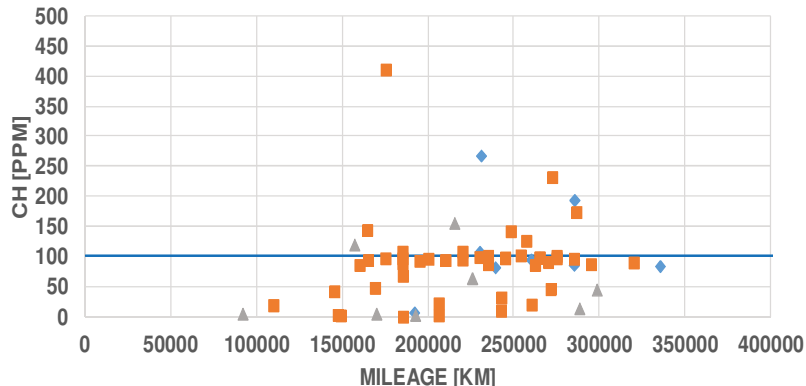

Fig. 11. HC test at elevated speed [11]

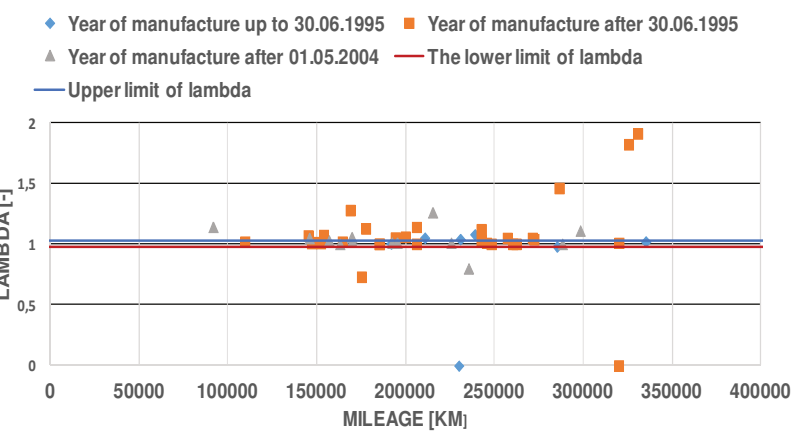

Fig. 12. Lambda study at idle [11]

The results of the measurement of the excess air ratio (lambda) are shown in Fig. 13. The tests were performed at low engine crankshaft speed of about $1000 \mathrm{rpm}$. The group of vehicles that were produced after 1995 did not meet the emission requirements in about $26 \%$. 
The measurement of the excess air ratio (lambda) was made at an increased engine speed (2000-3000 rpm). Results from the research they represent a group of vehicles manufactured after 1995 that do not meet the requirements of about $24 \%$ and vehicles manufactured after 2004 do not meet the required limits in about $5 \%$.

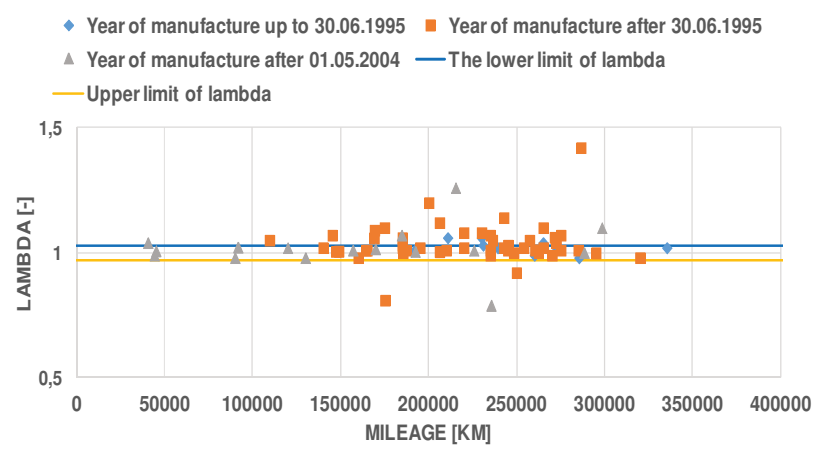

Fig. 13. Lambda study at elevated speed

\section{Conclusion}

The analysis of the number of vehicles in use in Poland shows that over $70 \%$ is over 10 years old. The average age of vehicles in 2015 was 15.5 years old. In the period from 2003 to 31 December 2015, 945,227 used cars were imported to the country, the average age brought in 2016 was about 12 years. During the periodic technical studies carried out, it has been shown that a significant proportion of the vehicles in service are not able to meet the required emissions limits. The research shows that the largest number of vehicles that do not meet emission limit values have been manufactured before 1995. The reason for not meeting the requirements of emission limit values for gas pollutants is too long car life and low technological advances of fuel supply systems and lack of modern exhaust aftertreatment systems.

\section{Nomenclature}

SI spark ignition engine

$\mathrm{CO}$ carbon monoxide
$\mathrm{CH}$ hydrocarbons

$\mathrm{CO}_{2}$ carbon dioxide

\section{Bibliography}

[1] MERKISZ, J., PIELECHA, J. Emisja cząstek stałych ze źródeł motoryzacyjnych. Wydawnictwo Politechniki Poznańskiej 2014.

[2] JABŁOŃSKI, J. Technologie ,,zero emisji”. Wydawnictwo Politechniki Poznańskiej 2011.

[3] www.eea.europa.eu/pl/pressroom/newsreleases/zanieczyszczenia związane z ruchem samochodowym 2015.10.24.

[4] www.eea.europa.eu/pl/pressroom/newsreleases/wielu-europejczykow-jest-nadal-narazonych 2015-10-24

[5] BIELACZYC, P., MERKISZ, J., PIELECHA, J. Stan cieplny silnika spalinowego a emisja związków szkodliwych. Wydawnictwo Politechniki Poznańskiej 2001.

Prof. Marek Idzior, DSc., DEng. - Faculty of Machines and Transport at Poznan University of Technology

e-mail: Marek.Idzior@put.poznan.pl
[6] Opracowano na podstawie www.samar.pl 2016-02-14.

[7] Opracowanie własne na podstawie GUS - wyniki działalności 2016.

[8] www.pzpm.org.pl/Rynek-motoryzacyjny/Park-pojazdowzarejestrowanych 2016.01.13.

[9] www.wsop.pl 2017.01.03.

[10] gazeo.pl/ 2017.01.14.

[11] Opracowanie na podstawie badań własnych w Stacji Diagnostycznej.

[12] Rozporządzenie Ministra Transportu, Budownictwa i Gospodarki Morskiej z dnia 26 czerwca 2012r. Dz.U. 2012.996 ze zmianami.

Edward Czapliński, MSc. - Faculty of Machines and Transport at Poznan University of Technology

e-mail: Edward.Czaplinski@put.poznan.pl 